\title{
ANTOINE LECLAIRE, THE FIRST PROPRIETOR OF DAVENPORT
}

\author{
By the Rev. Charles Snyder, Litt.D., LL.D.
}

He was a big man, this Antoine LeClaire," "The First Proprietor" of Davenport, Iowa. He was a big man physically. In a little notebook found among his papers ${ }^{2}$ in which he had written a varied collection of memoranda, he set down at times a notation of his weight. The high mark seems to have been on December 31, 1844, when he weighed 385 pounds. In 1849 he had shrunk to 368 pounds, and in December, 1850, the notation read 355 pounds. In height he was but five feet eight inches. It is said he had "a bon' structure." He needed it to carry that weight around. Indeed, in those middle years of life he did not attempt to carry it much in walking; he drove about the little city that he founded and about his neighbors' holdings in a buggy drawn by a white horse, both of which were as familiar tc the residents as the river. ${ }^{2}$ Yet it is said that LeClaire was graceful and light of foot in dancing and that he frequently enjoyed that pastime.

He was big of spirit, a man of vision, daring, almost audacious in the courage of his undertakings, generous,

The name is variously spelled in the old documents as LeClaire, LeClair, LeClere, LeClerc, LeClercq, with variations in the capitalization of the "C." The name is also ocea. sionally found spelled as two words, as Le Claire, etc. Antoine LeClaire himself wrote it in several forms. The name as spelled in the article is as it was most frequently found during
LeClaire's lifetime.

${ }^{2}$ After LeClaire's death his desk with a large number of unrelated papers came into the possession of the Davenport Academy of Science, now the Davenport Public Museum. They are now in the library of that organization in the Putnam Building. Davenport. The papers have recently bcen catalogued by Mr. John H. Bailey, Curator of the Museum, to whose courtesy and kindly helpfulness the writer is indebted for many references in this sketch, as well as to his secretary, Miss Alberta Boyd.

"In his painting, "The Ferry" or "'The River Scene," Johann Casper Wilde, a German painter, depicted LeClaire in his familiar buggy, drawn by the white horse, at John Wilson's ferry landing near the foot of present day Perry Street. The painting was made about 1845 . See Franc Wilkie, Davenport Past and Present, p. 309, and Aug. Richter, History of Daven. port. (German) pp. $83 \mathrm{ff}$. 
kindly, tolerant. Men, white and red, trusted him, honored him, believed him; and they generally followed the leadership of this second son of a French-Canadian and $\alpha$ woman of the Pottawattomies. He was a big man!

Antoine LeClaire was born December 15, 1797, at St. Joseph, Michigan. His father, also christened Antoine LeClaire, was, according to most of the printed references, born in Montreal, Province of Quebec. We know nothing else of the father until he is found located about thirty miles above Old Fort St. Joseph as a blacksmith and a trader. Here he took to wife a Pottawattomie Indian woman. As in most of those French-Indian martial alliances there apparently was no marriage ceremony."

In St. Joseph Francois was born, Nov. 17, 1795, and Antoine in 1797. His baptismal record reads: "Antoine LeClerc, natural son of Antoine LeClerc and Indian woman, born Dec. 15, 1797, baptised, St. Louis Cathedral, Nov. 29, 1815." Perhaps Josette, whose birth date is given as December 2, 1799, was likewise born in old St. Joseph, although concerning her we have no further informationhalf-breed Indian girls did not command much attention in those days. The fourth child, Joseph, who came February 15, 1801, and David, who arrived April 28, 1804, were born at the family's later home near Milwaukee. At about this time the Pottawattomie mother, who somewhere along the line had acquired the name of Marie Sauvagesse, died. According to the family account, the older Antoine later married a woman of French and Spanish descent, by whom he had other children. There is no other record of the second wife unless this old church record refers to her: "LeClerca, native of St. Antoine, Canada, son of Alexis and Angelique Renau married Felicite Gaud, widow of

Descendants of Antoine, Senior, living in Davenport and Moline have the story that his name was Antoine Francois, and that he came to America with the French troops in the years of the American Revolution.

The article. "Antoine LeClaire's Statement," an interview by the eminent historian. Lyman C. Draper, in Wisconsin Historical Collections, XI:238, is from the evidence of its contents, not that of Antoine, but that of Francois, his older brother. See also "Antoine LeClaire and the Beginnings of Davenport," a manuscript thesis by Mary A. Kinnavey, the State University of Iowa, 1919; Wisconsin Historical Collections, XVIII:445-"Mr. LeClaire had just arrived from St. Joseph," translated from the letter of Capt. Wm. Doyle to Charles Langlade, dated Michelmachinac, July 26, 1794. 


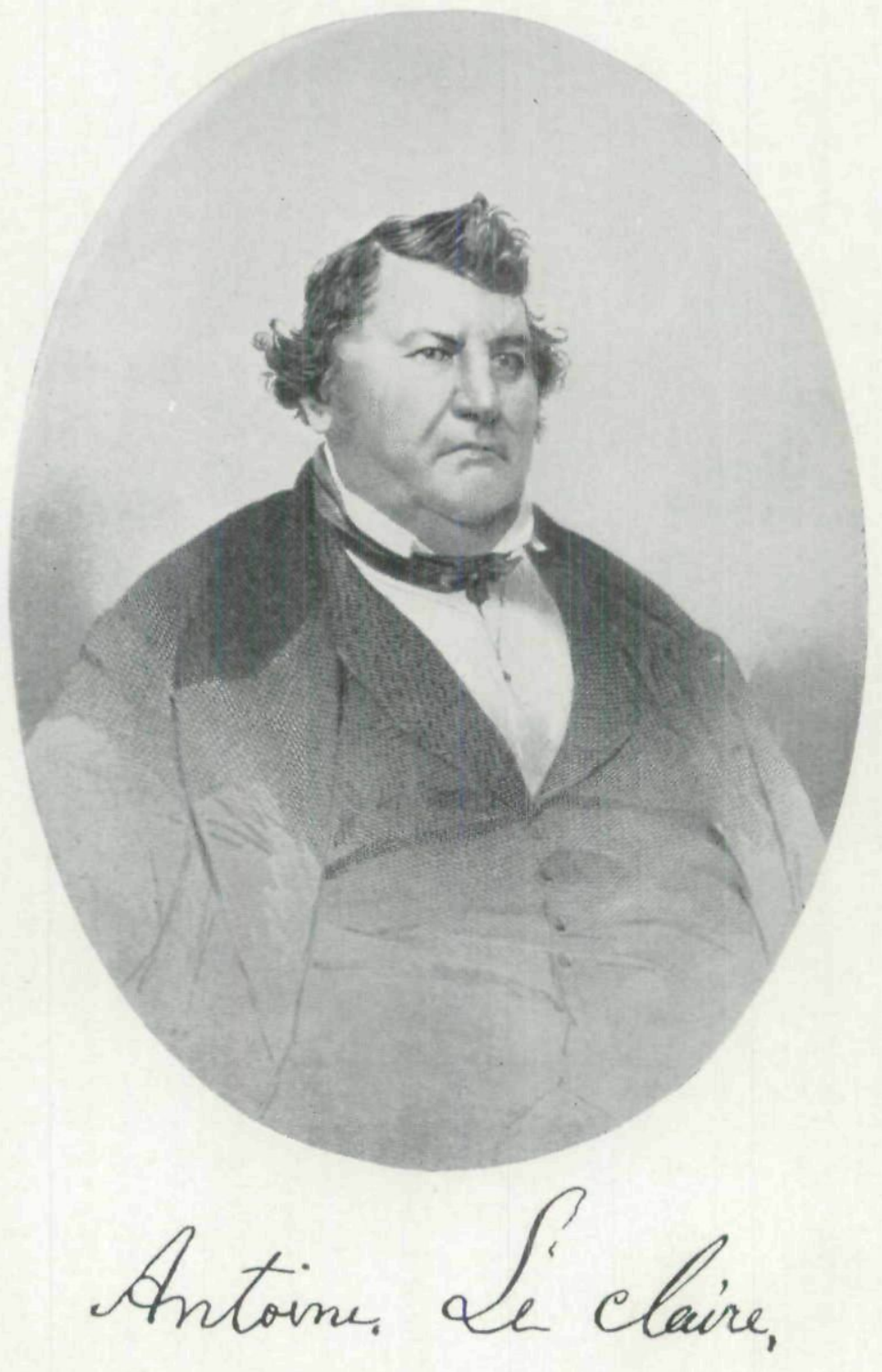


Louis Alexis Loise, married at Portages des Sioux Feb. 16, 1819. A previous civil ceremony had been performed.".* Descendants of the fourth child of the second wife, Antoine David, as well as grandchildren of Francois, the eldest son of the red woman who was renamed Marie, still live in Davenport. ${ }^{5}$

In 1800 Antoine, Senior, moved his trading post from Old Fort St. Joseph to the west side of Lake Michigan, on the east side of a river named for a nearby Indian village called Milwaukee, occupied by his wife's people, the Pottawattomies. At the time he located about three miles above the mouth of the Milwaukee River no other traders were then located there. In the white man's town that has since grown up around the spot where this earlier LeClaire first built his trading post, on the northwest corner of what is now East Water and Wisconsin streets, a large bronze tablet has been erected, which reads: "

The first house on the east side of Milwaukee was built on this site in the year 1800 by Antoine LeClaire as $\alpha$ trading post, the log house shown on the left of this view ...

LeClaire the trader remained on the shores of the Milwaukee as late as December 12, 1804. Later, about 1809, he was with John Kinzie on the Chicago River. In 1812 he was in Peoria, where he was one of the prisoners taken by Captain Thomas Craig in his ill-judged raid on that unfortunate town, and was among those who suffered loss in the loot taken and the damage wrought by the poorly

${ }^{5}$ Baptismal record furnished by Miss Stella M. Drumm, Librarian, Missouri Historical Society, from Old Cathedral Baptisms. See the younger Antoine's marriage contract, p. $864 \mathrm{c}$ Cf. Cyprien Languag Dictionnaire Genealogique des Families Canadienne; "LeClerc, Antoine. married 16 January 1819 at (Portage des) Sioux, Mo., Felicite Loise, baptised 1791, widow Sept. 1821. Josephine Boucher, daughter of Fabeth Beaugenoux, of St. Louis, Mo.; and 2, 3, Sept. 1821. Josephine Boucher, daughter of Francois and widow of Jean Louis St. Germain."
-Translation, by Miss Drumm.

"Wisconsin Historical Collections, XI:238.

The plaque also commemorates the settlement of Solomon Juneau in Milwaukee in 1825 The tablet was erected under the supervision of the Old Settlers 'Club of Milwaukee Count State Historical Society of Wisconsin. Information furnished writer by Miss Annie A. Nunns, 
disciplined American troops in that early western action of the War of 1812."

The results of this raid endured a long time. Although Ninian Edwards, when governor of the Territory of Illinois had reimbursed the French at Peoria out of public funds for part of their loss, LeClaire and twelve others petitioned the Congress of the United States in 1820 for redress and "relief." Congress passed two bills which granted further aid to the French inhabitants of Peoria. These acts gave the French title to their properties there, but it was not until 1840 that the necessary surveys were made by which letters patent could be granted."

In 1813 the elder LeClaire settled at Portage des Sioux, Missouri territory, on the peninsula between the Mississippi and the Missouri rivers, where the "West moves out to meet the North," and where Lewis and Clark turned in in 1804. LeClaire, Senior, returned to Peoria sometime thereafter. In 1816 he received an appointment from A. Graham, Agent of Indian affairs in the Territory of Illinois as "interpreter to the Pottawattomie Nation of Indians within the territory of Illinois; to reside at Peoria or such other place as the Superintendent of Indian affairs may direct."

The elder LeClaire moved from Peoria to Portage des Sioux once again, however, sometime before 1819, when he was married a second time in the latter place. ${ }^{10}$ There or at the neighboring St. Charles he seems to have spent the rest of his days, although among the LeClaire Papers is a brief notation in the hand of William Clark, which suggests still later movements.

TOne account has it that in 1812 a vagabond named Elijah Bruce had been driven from $\mathrm{AuPe}^{\prime}$ (Peoria) for misconduct. He hurried to Kaskaskia and reported that the inhabitants were aiding the British supply their Indian allies. On Nov. 5, 1812. Capt. Craig landed his were aiding the British supply the town, in which Thomas Forsyth, Indian agent, was the only one who could speak men in the town, in which Thomas Forsyth, the on and drinking too much wine the troops moved down the river, only to return next day to loot the church and carry away boat loads moved down the river, only to return next day to loot the church and carry away boat loads of prisoners, many naked, and or shelter.- See James Gray, The Illinois, pp. $85 \mathrm{ff}$.; C. Ballance, History of Peoria. IIlinois, 1870 , pp. $28 \cdot 40$.

speoria Journal-Transcript, July 16, 1933.

"LeClair Mss. The Forsyth collection of mss. in the Wisconsin Historical Society con. tains other references to the older LeClaire. Both collections have several memoranda of trans. actions between the two men-in French-about 1818. The commission is in the LeClaire Mss.

10 See p. 80 above. 
In the event of the absence of Mr Latham the sub agent from Peoria, on the arrival of Mr. LeClaire the United States Blacksmith at the place, the smith's tools belonging to the Indian Department will be delivered to him.

St. Louis, January 20, 1825

Wm. Clark

The statement of the eldest son, Francois, that the father's death occurred in Portage des Sioux may be taken as final. But in lieu of the definite statement and description of William Clark, that son's further statement that the father died "about 1821" can hardly be accepted. More probable is the local family record that Antoine LeClaire, Senior, died in August, 1825. ${ }^{12}$

That Antoine, Senior, had his family with him in Peoria is evident from their early presence with him on the Mississippi, and from stories relating to the younger Antoine in Peoria. Though only a boy, "Antoine LeClaire claimed two lots, 80 by 300 French feet. These lots were on Main Street in La Ville de Maillet [Peoria]."

From records in the recorder's office, in 1857 LeClaire sold these two lots, numbers twenty-five and twenty-six, for $\$ 1,000$. The lad was also a clerk in the store of Felix Fontaine, according to another writer. Still another bit of evidence, which it is assumed relates to Antoine, is significant. On June 8, 1812, in a letter dated at "Piorias," Thomas Forsyth, Indian agent in the village-fort, wrote Governor Edwards at Kaskaskia, "I have agreed with Mr. Leclerc to make the tour you wish him to make. As he could not go alone, he takes his son with him. I have agreed to give him $\$ 2$. per day, and should the Indians steal his horse, the Government is to replace his horse by giving him another-also some provisions. ${ }^{12}$

Down in St. Louis General William Clark was Superintendent of Indian Affairs, a position he had held since 1807 and his return from his famous western exploration with Meriwether Lewis. Governor of the Territory of Missouri since 1813, he continued in the two positions until Missouri

\footnotetext{
${ }^{11}$ Wisconsin Historical Collections, XI:238.

${ }^{12}$ Peoria Journal-Transcript, op. cit.; Miss Drumm, see note 5.
} 
became a state in 1820, resuming the office of Superintendent of Indian Affairs shortly thereatter. He was Governor of the Territory of Missouri when first John Campbell and then Zachary Taylor were sent up the Mississippi River in 1814-15 with relief for Fort Shelby at Prairie du Chien. Both expeditions came to grief from attacks by the British and their Sauk allies near by the mouth of the Rock River and what later became the shores of Davenport, in which encounters appeared the figure of Black Hawk, a Sauk warrior later to become well known to Antoine LeClaire. The Indians of the middle west generally were British allies in that second war with England, which for years had carefully cultivated the friendship of the red tribes with gifts and annuities. ${ }^{13}$

Among those associated with Clark in controlling the Indians of the West were Governor Ninian Edwards of the Territory of Illinois, and Auguste Chouteau, head of the famous trading house in St. Louis, and nephew of the founder of that city. All had much to do to keep the tribes of the Mississippi Valley quiet, and they had immeasurable influence. One of their active assistants was Nicholas Boilvin, another French Canadian, who in 1806 became the first agent over the Indians in Iowa. His orders from General Dearborn, then Secretary of War, read that he should go to the "sacque" village at the rapids of the Mississippi, "above the mouth of the River Le Moin," and make that his principal place of residence, and that he should proceed from there to Prairie du Chien."

Another man upon whom Clark and his subordinates depended was the same Thomas Forsyth who was one of the victims of Craig's men at Peoria. Born in Detroit in 1771 of an Irish father, a younger half-brother of John Kinzie of Fort Dearborn fame, Forsyth entered the fur business as a clerk in 1790, and six years later with a partner established his own trading post at Quincy, Illinois. In 1812 he was appointed a sub-agent for the Indians at Peoria,

\footnotetext{
13 Dictionary of American Biography, "William Clark," cf. also Holman Hamilton, Zachary Taylor, Soldier of the Republic, 1941, I. pp. 49.53 and "The Life of Black Hawk."

${ }^{14}$ The Iowa Journal of History and Politics, XIV:350
} 
and in 1819 was made a full agent at Fort Armstrong on Rock Island. He retired in 1830 and died in St. Louis in 1833. He was another of those valuable men, kindly, generous, understanding, honest, whom the red men trusted. ${ }^{15}$

Now Governor Clark was a far-sighted administrator who realized that as it comes to all men age would come to him and to his colleagues and that other and younger men should be trained to succeed them. He had a way of picking out likely boys for such training, including several Indian boys whom he had educated. "He lists in his reports "tuition, books, clothing, etc. for Jean Baptiste Charbonneau; one year tuition paid to J. E. Welch, a Protestant Minister, and another year paid to Francis Neil, a priest. Rev. Mr. Welch was a Baptist minister who boarded and educated Indians and half-Indians, while Father Neil conducted a school for boys which was the predecessor of St Louis University."16

Among the boys whom Clark picked out for an education was the young Antoine LeClaire, who came to evidence an especial aptitude for languages. The tradition is that he spoke fourteen or fifteen Indian tongues-one story has it seventeen. He also spoke French, Spanish, and Englisb; "he learned to speak English well with a French accent."17

Meanwhile, in 1818, when but twenty-one years old, Antoine the younger was sent to Fort Armstrong as an interpreter where he renewed an acquaintance begun at Fort Clark, Peoria, with an Englishman who had but two years before established a trading post on Rock Island. His name was George Davenport. In later years the two men were to be engaged together in innumerable undertakings, one of which was the founding of a city which LeClaire insisted should be named for his friend, Davenport.

Colonel Davenport, born in England, had come to America as a sailor in 1804 . While he was recovering from

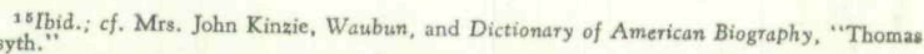
Forsyth."

${ }^{16}$ Stella M. Drumm, op. cit.; American State Papers, Indian Affairs, vol. 2. op. cit.

1"Rock Island Railroad Magazine. Seventieth Anniversary Number, 1922; Aug. Richter,
cit.
} 
a broken leg in New York Harbor, his ship sailed away without him. He joined the United States Army, and was sent to New Orleans, where he saw much service in the Indian country, particularly during the War of 1812. His term of service expiring in 1814, he came to St. Louis where he engaged in the Indian trade, and helped Governor Clark keep the tribes appeased. In 1816 Colonel Lawrence, who had first induced Davenport to join the army back in New Jersey in 1804, was sent with the eighth regiment and a company of riflemen to build a fort on Rock Island. Davenport accompanied his old friend, opened up a trading post, and began an eminent career as a trader, a promoter of cities, and a friend of the Indians. ${ }^{18}$

In 1820 back at Portage des Sioux, Antoine became engaged to marry a Peoria girl named Marguerite LePage, whose father was Antoine LePage and whose mother was a Sauk woman, granddaughter of Ac-co-qua, once chief of a Sauk band. The quaint marriage contract was drawn up in French and signed November $6,1820 .^{10}$

\author{
November 6, 1820 \\ Treaty of Marriage \\ Between Antoine LeClaire \\ And Marguerite LePage
}

There were present Antoine LeClaire, of age, making use of his rights, a native of des Pes, son of Mons. Antoine LeClaire and of Marie Sauvagesse, his father and mother on one side; and Mlle. Marguerite LePage, the daughter of Mons. Antoine LePage, and of Madame Victoire Blondeau, native of this parish, her father and mother on the other side.

The said parties, with the advice and counsel of their relatives and friends here assembled, that is to say, on the side of Antoine LeClaire: Sire Antoine LeClaire, his father; Sire Francois LeClaire, his brother; and Sire Andre St. Amant, contracting for him and in his name-and on the side of the said Mlle. Marguerite LePage; Sire Simon LePage, her uncle; Victoire Blondeau, her mother; Sire Patrice Roy; and Sire Etienne Bienvenu, all relatives and friends, contracting for her and in her name.

\footnotetext{
${ }^{18}$ Richter, ibid.; Wilkie, op. cit., pp. $145 \mathrm{ff}$.

${ }^{10}$ LeClaire Mss. Note signature of father and elder brother of the groom. Etienne Bien. venu married Marguerite's sister.
} 
Both have made voluntarily this contract and agreed together in this marriage document to execute the following, that is to say that the above mentioned Sire Antoine LeClaire and Mlle. Marguerite LePage have promised and promise to take each other reciprocally for future and lawul husband and wife with their goods and rights belonging to them whether by succession, donation, legacies, or otherwise, and this marriage to take place in the presence of our Mother, the Holy, Catholic, Apostolic, and Roman Churches as soon as it can be arranged for when one of the two will request it of the other.

The said future husband and wife will be one and hold in common all the goods, movable and immovable, bought and acquired during and throughout their future marriage, irrespective of the site or place they will be located.

However, the said husband and wife will not be responsible for any debts acquired and contracted before the celebration of this future marriage, but if there are any debts outstanding, they will be paid and cleared, out of his or her personal wealth by he or she who will have contracted them, without the other party being obligated in any way whatsoever.

As a favor for this marriage, the said future husband has endowed, and endows the said future wife with the sum of sixty Piastres in good United States money. This fixed dowry, once paid, is not returnable and she will have and take it as soon as the dowry has been raised on all the present and future goods, movable or immovable, of the said future husband. Both will have the responsibility to secure and establish together the said dowry and other agreements of the said future wife without her being obliged to demand it by law.

The survivor of either future husband and wife will have and take, by preciput, from the movable goods they hold in common, according to his or her wish, after the inventory and without increase in value, up to the sum of thirty piastres or the same sum in deniers, according to his or her choice.

It will be permitted to the said future wife and to her children to withdraw from the estate held in common during the life of the future husband or after his death, and to take back honestly and fully the goods she contributed to the marriage, as well as any good. she might have inherited during her marriage, including her dowry and the mentioned preciput.

In the name of the good friendship that the said future husband and wife have for one another, these present irrevocable donations have been made from all the movable and immovable goods bought or acquired together and which will be existing at the death of one or the other, to be enjoyed by, and disposed of, in full liberty, by 
the survivor from the day of the death of the first departed. In the event that there are no children born or to be born from this said future marriage, these donations will become null and void.

This has been agreed to and executed at the Portage des Sioux, November 6, 1820.

Antoine LeClaire, father

Victoire Roy

nee Blondeau

Antoine LeClaire

Her

Marguerite X LePage

Mark

Witnesses

Witnesses

Andre X St. Anan

Patris X Roy

Francois LeClaire

Simon X LePage

Equien $\mathrm{X}$ Bienvenu

The religious record of the marriage ceremony reads: "Antoine Leclerc of St. Joseph Canada [sic] son of Antoine and Marie, an Indian, married Margaret LePage, daughter of Antoine and Victoire Blondeau at Portage des Sioux," and bears the date, November $20,1820 .^{20}$

After his marriage young LeClaire took up his residence in Portage des Sioux, where his energy soon commended him to his neighbors. He became a town trustee, helped organize a military company, and acted as Superintendent of the Indian Agency. ${ }^{21}$ An old commission found among his papers indicates that a few years later, on February 3 , 1825, he was appointed Justice of the Peace for the township of Portage des Sioux by Frederick Bates, Governor of Missouri, for a "term of four years unless sooner removed."

But on the other hand, there were numerous interruptions in his residence at the Portage. The record shows that the same year in which the twenty-three year old Antoine married Marguerite at Portage des Sioux, he was sent out into the Arkansas region by governmental order "to observe the restlessness of the Indians." How much time he spent in the southwest the memoranda again do not show. He must have spent more than a few months

${ }^{2}$ Stella M. Drumm, op. cit.

${ }^{21}$ Richter, op. cit.; LeClaire Mss. 
among the western tribes, for he remained long enough to become thoroughly acquainted with the languages and to impress them with his friendliness. In June, 1825, just four months after his commission as Justice of the Peace in Portage Township was signed, LeClaire was acting as interpreter in St. Louis in the making of treaties between the Osage and the Kansa peoples. It was toward this office as interpreter that his education was bent, for which he was particularly gifted as a natural linguist, and in which occupation he was well trained in his associations with his father who had performed similar tasks before him. ${ }^{22}$

The position of interpreter, however, was not usually $a$ lucrative one. The usual salary for such a functionary was $\$ 500$ a year; and if a sub-agent acted in that additional capacity, the $\$ 500$ was added to his regular salary. This position, like the agency blacksmith, who received $\$ 480$ a year, was filled by appointment by the Superintendent of Indian affairs, or the post agent. ${ }^{23}$

In 1827 the still youthful LeClaire returned once more to Rock Island on the upper Mississippi, where he engaged in business as a trader, partly on his own account, partly associated with his friend George Davenport, and partly representing at an up-river post the powerful Chouteau firm in St. Louis. Together with his wife, Marguerite, he occupied a small house on the island, where he dealt with the many Indians nearby both in a business way, and as a counselor and friend. In the meantime, he served the post and Indian agency at Fort Armstrong as its regular interpreter.

Indicative of the services this large-framed son of a French Canadian father and a Pottawattomie maid was rendering the government's agent at Rock Island is the letter received from the latter, Thomas Forsyth, in 1829: ${ }^{24}$

\footnotetext{
22 Ibid.

2 Iowa Journal of History and Politics, op. cit.

Even fixed salaries varied for interpreters. In the first year of the Territory of Iowa the salary was $\$ 300$ per year for an interpreter for the Sauk and Fox tribes - see reports of the Governors of the Territory of Iowa, as Supts. of Indian Affairs, Manuscript Division, Iowa Dept. of History and Archives.-Editor.

24LeClaire Mss.
} 
Dear Antoine:

St. Louis 23 February, 1829

Your letter of the 12th ult. I received and thank you for its contents. I very well remember what Morgan told us last summer, and I have no doubt but the difference in opinion between him and his chiefs, have occasioned all the trouble now existing between the Sauk and Fox Indians and Sioux Indians.

About 17 days ago a part of 19 Sauk and Fox Indians arrived here on $\alpha$ visit to General Clark, among the number was Perhapaho, Wabalaw, Wawcomie, Keeocuck and the Strawberry's oldest son. Their business was to see and speak to General Clark on the subject of loosing their Chief Keemot Wugamaw, and to get permission to stand on their feet for $\alpha$ white. General Clark not being here, I committed this communication to paper and sent it on to General Clark at the City of Washington. Those Indians also told me, that they had left the Yellow Bird in charge of the younger men during their absence, and all would be quiet until they returned home, that after they got home, they would keep all quiet until my arrival at Rock Island (in April next) with Gen. Clark's answer. I wish you would tell all the Indians you may see that the Sauk and Fox Indians must remain quiet until I arrive at Rock Island with Gen. Clark's answer to the paper of the Chief I sent on to Washington City to Gen. Clark as the Chief have promised "so to do when here. My health has been good this winter, altho we have had some extreme cold weather latterly. Horses with loaded wagons have been crossing the Mississippi on the ice for sometime past, and when we shall have fine weather again, is hard to say. You ought not wish me to excrse your writing, it is good, but there is some bad spelling, which all ought to be excusable in a person like you who never was taught, all you want is practice in writing, and a dictionary at hand, then you would do well.

My family thank God are now all well and I hope will continue in same good health. Give my respects to Mr. and Mrs. Casners, M. S. Madam Lebeau and tell Baptiste all his family was well a few days ago when I was in town last.

Give my best respects to your wife and am happy to hear of good health. Your little Brother David was well a few days since.

\author{
I remain \\ Your friend \\ Thomas Forsyth
}

To Antoine LeClaire)

Rock Island

The fragmentary evidence offered by the LeClaire papers indicates that while part of his father's family were at this 
time living in St. Louis, Antoine's elder brother, Francois, was, like Antoine, working for the United States government, presumably in the vicinity of the agency at Fort Armstrong. ${ }^{26}$

The United States Indian Department

To Francois LeClaire ...

For my services while employed by Mr. Forsyth [late Indian agent] to aid the Sacs and Foxes in Agriculture from the first of July to the 15 th of September, 1830, inclusive, 77 days at $\$ 1.10$ per day. $\$ 84.70$.

Indorsed on this statement is the following:

Received St. Louis 30th September, 1830 of Gen. Wm. Clark, Supt. of Indian Affairs Eighty four dollars and seventy cents in full of the above account.

\section{[signed duplicates] \\ Antoine LeClaire for \\ Francois LeClaire}

A letter written by Antoine LeClaire from Rock Island just four days before the above offers interesting insight into his relationship to the Indian agency at the Fort and to the traders supplying the Indians at that post:

Rock Island

September 26, 1830

Dear Sir:

I received your letter dated July 6 th in which you request to be informed of the quantity of good that the Indians want for their annuities, and of what kind, you having had the offer from Mr. St. Vrain they offer to pay the annuities.

I did not answer your letter at the time being of the opinion that any information I could give you would be of very little service, that when Mr. St. Vrain became acquainted with the Indians he would know that he could make no arrangements with you to pay the annuities to the Sac and Fox Indians. I have no doubt but he would give you this information. The agent pays to the Indians their annuities in cards. The Indians purchase their goods of Messrs. Farnkans and Davenport. These gentlemen have furnished the Sack and Fox Indians goods for the last fourteen years and have all ways supplied them on credit to enable them to hunt to support their families.

solbid. 
I did in the course of conversation say to Mr. Davenport that inquiry had been made by Mr. Menard Clerk respecting what kind of goods would be wanting for the annuities-but Sir with no intention to injure you, I have since learned that Mr. Davenport wrote to $\mathrm{Mr}$. Chouteau the particular friend of Col. Menar on the subject-but I have not heard that Mr. Davenport has said one word to any other person on the subject.

I am surprised at the tennor of your last letter, in which you observe that the letter sent by Mr. St. Vraine was merely to let me know he was agent in order that I should treat him as such for fear, of losing my place WHICH I MIGHT DO IF I DID NOT BEHAVE WELL. I have never solicited your interest to keep me in my situation, I hold it by faithfully doing my duty, and ask no favors of any one.

I must take the liberty of advising you to be more discreet in writing letters on business or you may lose your pLACE. Should that be the case as we are townsmen and Creoles, I will use my interest to procure you another situation.

To A. C. Lesieur

I am your $\mathrm{Ob}$. Servant Anthony Le Clair

The valley of the Mississippi, however, was beginning to witness a steadily increasing stream of white settlers, traders and government agents, pushing farther and farther into the once secure Indian domain. In the conversations which must have frequently ensued between the Indian agentswho significantly enough were attached to the Commissioner of Indian Affairs' office under the War DepartmentAntoine LeClaire found his services in much demand. He became intimately acquainted with Keokuk, Black Hawk, and other leaders of the Sauk and Fox tribes in the villages on both sides of the Mississippi. Suggestive of the type of employment had by an "interpreter," and his means of payment, is the claim note made by LeClaire against the federal government for services rendered in $1831 .^{26}$

The United States Indian Department

Dr. 1831 )

Dec. 31 ) To Antoine LeClaire

To his services rendered as Interpreter for the Sacs and Foxes, three months, vis: from the lst October to 31st December, 1831 $\$ 100$. 
I certify that the foregoing account is correct and just and that no part of the same has ever yet been paid: although duplicate receipts were given by me to the late Felix St. Vrain, Esq. then Agent of the Sacs and Foxes, as has always been customary by those employed in the Agency to enable the Agent to make out his accounts estimates and that he may settle with the Superintendent of Indian Affairs and draw money to defray expenses of the Agency for which these receipts are always previously given.

Being absent on duty, at the return of the Agent from St. Louis and having no opportunity to get my pay from him, it remained in his possession until the period of his untimely and lamentable death; having been killed by the Indians in May, 1832. All the others, employed in the Agency, having received their pay, and the subscriber humbly hopes that equal justice may be awarded to him.

Antoine Le Claire
) Sct.
State of Illinois )
Rock Island County)

Personally appeared before me, a Justice of the Peace, in and for the County and State above mentioned, Antoine Le Claire, who made oath that the foregoing statement is true and that he has received no part of the account there charged. Given under my hand and seal this 13th July, 1838.

Jn. A. Barsell J. P. (Seal)

These were busy years, but this man LeClaire was always busy, down to the last year of his life. He was also accumulating considerable wealth by virtue of his trade with the various Indian bands under the control of the agency at Fort Armstrong. As the white men came in growing numbers, he had a vision of farms and cities growing along the banks of the Mississippi. He saw that their coming meant inevitable collision with the red tribes, and he set himself to the task of being the friendly advisor of the bewildered Indians, who not only found themselves involved in the white man's way of trade, but in the white man's hungry demands for land on which to settle. Due perhaps to their long associations with the red men, LeClaire, Davenport, and Forsyth kept the confidence of the Indians to a remarkable degree- that is, all except for the time when Black Hawk, emotionally torn by the outrages his town of 
Saukenuk and his people had suffered, failed to understand efforts that Colonel Davenport and LeClaire were making to keep the peace and became blazingly angry with them. Though Black Hawk was well acquainted with LeClaire between 1827 and the outbreak of the war in 1832, the chief resented in his bewilderment LeClaire's persistent and consistent advice in the fateful months which preceded the outbreak-advice to follow the suggestion and example of Keokuk. At one time the aged Black Hawk complained that LeClaire was "equally as bad" as the others who would have persuaded him to move, although he confessed in almost the same breath that LeClaire gave him "so many good reasons that I almost wished I had not undertaken the difficult task" of defending the village against enroachments of the whites. When Thomas Forsyth, the agent, was removed in 1830, Black Hawk took his departure as a personal affront. ${ }^{27}$

As United States interpreter at Rock Island, LeClaire was frequentiy sent to various tribes to talk them out of their irritations with the whites and to settle tribal feuds. It was he and Forsyth, and Davenport, who persuaded Keokuk to cross the river to the west, obediently to the government's order and to persuade him further that peace was the better way when Black Hawk took up the tomahawk.

Black Hawk refused to listen to the repeated good counsel of Forsyth, St. Vrain, his successor, LeClaire, or Davenport. He suffered enough indignities and crimes from the hands of the white men to justify his own anger, besides having brooded long over the wrongs to his people, bint he undertook a hopeless cause. When it was all over after the massacre of the Sauks at the Battle of the Bad Axe in August, 1832, a conference was called between the whites and the Sauk chiefs. It should have met on Rock Island at Fort Armstrong, but an epidemic of cholera was raging from the Great Lakes to the Mississippi, and there

${ }^{2 \tau} \mathrm{Life}$ of the Ma-Ka-Tai-Me-She-Kia-Kiak or Black Hawk, etc., dictated by Himself. The book was published in Boston, New York, Philadelphia, Baltimore, and in Mobile. See pp. 86. 104 . 
were many ill at the Fort. In consequence, the big treaty tent was pitched in what is now Davenport, at Fifth and Farnam streets. There on the twenty-first of September, 1832, General Winfield Scott of the United States Army, Governor John A. Reynolds, of Illinois, on the one side, and the Sauk chiefs, led by Keokuk, on the other, met and agreed to the "Black Hawk Treaty." But Black Hawk was not there. The beaten chief was the white man's prisoner at Prairie du Chien. The interpreter in the making of the treaty of September 21, was Antoine LeClaire.

The story has been often told that Keokuk insisted that the section, or square mile of land where they met, should be given to Antoine and Marguerite as a token of the respect, gratitude, and affection the Sauks held for them. In the treaty it is simply set down in Article 6 that one section of land opposite Rock Island and one section of land "at the head of the first Rapids," be assigned to Antoine LeClaire. The Pottawattomies, his mother's people, had likewise insisted that a section of their land east of the river should be given him; a part of that section is included in the present city of Moline. ${ }^{28}$

In the section of land "at the head of the first Rapids" is the little city of LeClaire, which Antoine started to develop by taking into partnership George Davenport, Enoch March, and Governor John Reynolds of Illinois. Later Captain James May bought out March, and thereby started a train of events that led to a tortuous lawsuit many years later.

After Black Hawk's return from the East where he had been taken by his Great White Father to see and be impressed by the power and resources of the pale faces, and after he had set himself down in his little house along the Des Moines River in Davis County, Iowa, the aged warrior conceived the idea of writing a book containing his reminiscences, for the benefit of the white man. His anger had cooled, and he wanted to be friends with the men of whom he had thought but ill a few years before. It was to LeClaire, the United States Interpreter at Rock Island, the man whose

2sWilkie, p. 168; Annals of Iowa, First Series, 1: 146. 
advice he thought so mistaken a year before, that he turned to tell his story which resulted in the famous "Black Hawk Autobiography." LeClaire translated it into English, it being taken down and edited by J. B. Patterson, editor and publisher of a Rock Island newspaper. Instantly popular, when it first appeared in 1834, the book did not escape, however, a loud chorus of disbelief. Critics said that no untutored Indian could have told a story like that, claimed that "it was got up by Mr. Antoine LeClerc, etc." Another thought that Patterson had colored the account in his "editing". But this book which has added so materially to the fame of the Sauk Black Hawk, when published was prefaced with the statement of Antoine LeClaire:

I DO HEREBY CERTIFY, that Ma-ka-tai-me-sh-kia-kiak, or Black Hawk, did call upon me, upon his return to his people in August last, and express a great desire to have a History of his Life written and published, in order, (as he said) 'that the people of the United States ... might know the CAUSES that had impelled him to act as he had done, and the PRINCIPLES by which he was governed.' In accordance with his request, I acted as Interpreter; and was particularly cautious, to understand distinctly the narrative of Black Hawk throughout-and have examined the work carefully since its completion-and have no hesitation in pronouncing it strictly correct, in all particulars." 29

It was Black Hawk's work and there is no other work in the world like it. It is remarkable as the work of an Indian, it is also remarkable as the work of the interpreter who rendered the Sauk words into English. In such a cooperative enterprise, one can only assume the pleasure of the interpreter in receiving the following letter: ${ }^{30}$

\footnotetext{
${ }^{20} \mathrm{Life}$ of Black Hawk, loc. cit. LeClaire is always referred to impersonally by Black Hawk as "the interpreter," or the "United States Interpreter," never by name. One can only won" der what else the warrior might have recorded about LeClaire had another translated his "Life."-Editor.

2 LeClaire Mss.
} 


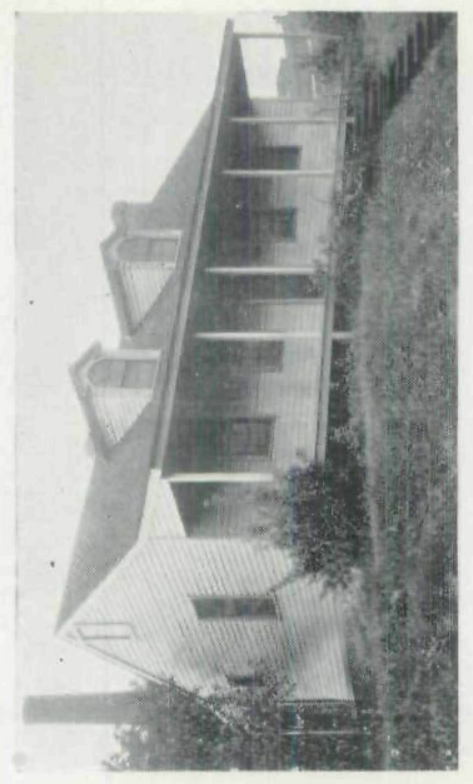

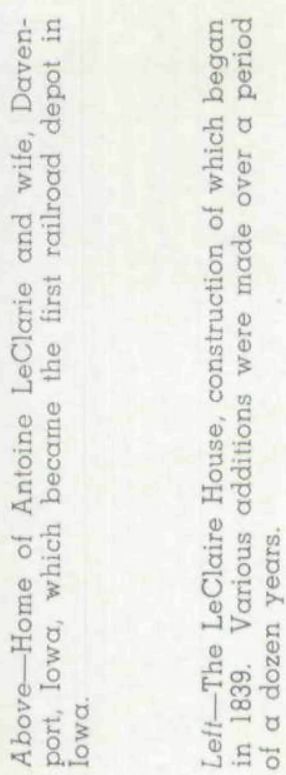

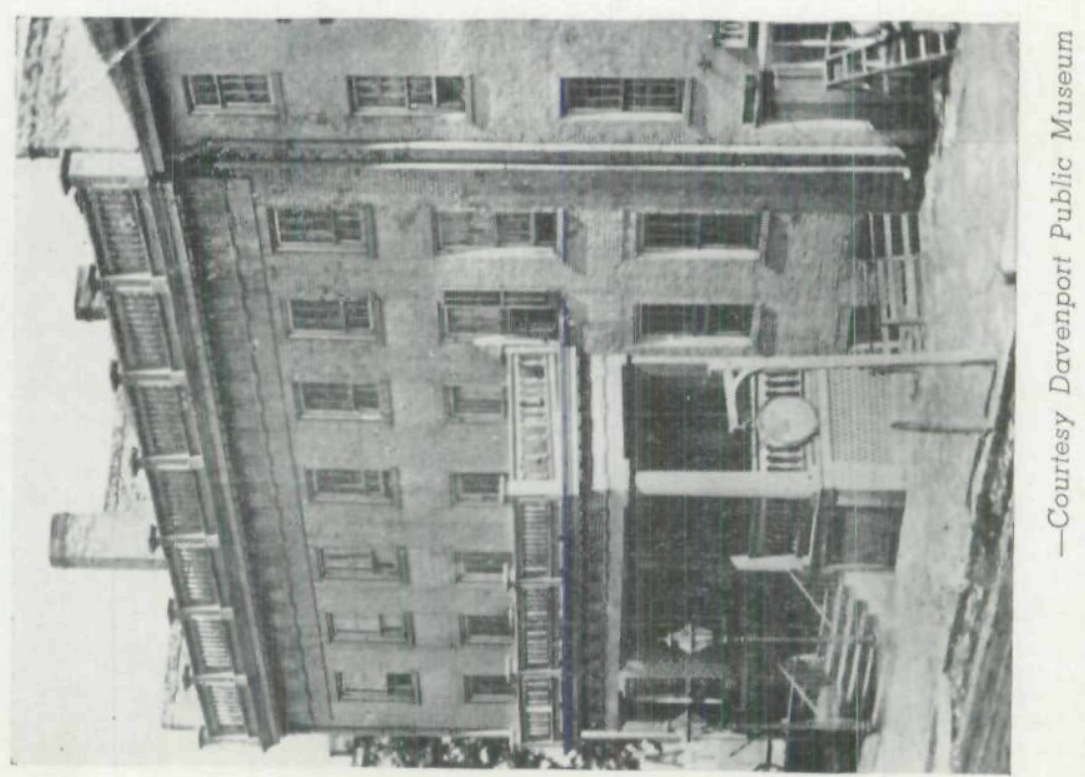


Gov. Antoine Le Clair

Boston, February 6, 1834

My dear Sir:

I would have written to you long since, but had nothing worth while to communicate. I have been waiting with a hope, that I would soon be enable to have something subSTANTIAL to say.

As yet, I have made nothing out of Black Hawk. An edition is now being published in this City. It will be out in a few days. After which I can give you an account how it takes.

You will see by the papers, which I will send you hereafter, how it is puffed. You have been raised in the estimation of the folks "down East" very much. They look upon you as a first rate Interpreter, such, they, say, as the Gov't. ought always to have in office. The people are much in favor of the Indians. They look upon them as a people that have been badly treated and they are honest and fearless enough to promulgate their opinions.

I am now dramatizing Black Hawk. That is, I am writing an Indian Tragedy which will be performed in this city. I have a full dress with me, and will personify an Indian character in the piece myself. I will let you know how it takes, when I write again, which will be soon.

I do not like to be in a crowd. I am tired of cities. I would prefer the solitary prairie, where I could hear no man's dog bark but my own.

How much more pleasant it is, when the cares of the day are over, to sit down in your domicile, and have your family and friends around you, than it is to be in a large city like this, where every face is a stranger to you.

At home, where all around are friends and acquaintances, you can sit down and pass away your time in social chat, or in playing with the children (not your's, I had almost forgotten that you had none.) Here there are always forms and ceremonies to go through, that would make an easy man feel unpleasant.

Give my respects to your family, and Mrs. Burtis-and also, old Gen. Black Hawk. The people here would be glad to see him. They look upon him as a much injured Brave. I am getting $\alpha$ steel ENGRAVING of him for the frontispiece-it costs $\$ 50.00$.

With great respect,

I am sir,

Your friend

Addressed to:

J. B. Patterson

Monsieur Antoine LeClair

of Le Clairsville

Rock Island, Illinois 
The treaty which produced the "Black Hawk Purchase" did not end the chapter of treaties for Indian land in Iowa. Nor did it end the work of LeClaire as government interpreter in a number of other treaties which followed. The full list of treaties to which his name is signed is: ${ }^{31}$

1825, Treaty with the Osage, interpreter, June 2.

1825, Treaty with the Kansa, witness, June 3

1829, Treaty with the Chippewa, Ottawa and Pottawattomie, interpreter, July 29

1829, Treaty with the Winnebago, witness, August 1

1830, Treaty with the Sauk and Fox tribes, interpreter, July 15

1832, Treaty with the Winnebago, witness, September 15

1832 Treaty with the Sauk and Fox tribes, interpreter, September 21

1836 Treaty with the Sauk and Fox tribes, interpreter, September 27

1836 Two treaties with Sauk and Fox tribes, interpreter, September 28

1837 Treaty with the Sauk and Fox tribes, Interpreter, October 21

1842 Treaty with the Sauk and Fox tribes, interpreter, October 11

LeClaire was also present at the Conference at Agency, Iowa, in October, 1841, when no agreement could be reached and "no sale" of Indian land was made. Governor John Chambers, acting as Superintendent of Indian Affairs, was exasperated with the traders; and he seems to have had an aversion for the Chouteau company of St. Louis, operating under the name of the American Fur Company, which they had acquired. He exiled the Chouteau representatives to their trading house, about a mile from the agency buildings, and placed a guard about them. Among those "prisoners" were Davenport and LeClaire, whom the Governor suspected of having too much influence with the Indians, who were holding back from Chambers' proposals. Franc

317 U. S. Stat. at Large (Indian Treaties), 240, 244, 320, 323, 328, 370, 374, 516. 520, 540, 596 . 
Wilkie repeats this story, aithough substituting Governor Lucas for Governor Chambers. Inasmuch as Lucas had been succeeded by John Chambers the spring before this meeting was held at Agency, it is evident that Wilkie was confused, and inasmuch as Lucas had a grudge against the Chouteau firm, the incident may have occurred at a meeting held in 1840 when the Indians were called together for a division of annuities - and it may be only tradition."

Negotiating Indian treaties and agreements was always a difficult job, especially when confronted with the diverse elements such as constituted the remaining bands of the Sauk and Fox. Something of the difficulty that Governor Chambers experienced in 1841 is indicated by the following letter from the LeClaire Mss.:

Davenport August 28th, 1841

To his Excellency Chambers

Governor of Iowa Territory.

The undersigned Chiefs and Braves of the Fox nation beg leave respectfully to represent to your Excellency that some time during the last spring we understood that it was the wish of the Government of the United States to purchase the lands of our Nation in this Territory that we have ever since been expecting to receive some communication from your Excellency or from our Agent on the subject; but up to this time, we have received no such communication from either. Recently we have been induced to believe (for reasons not necessary now to trouble your Excellency with) that the Sauks have determined to hold a treaty with and sell to the United States a large body of their lands (or rather of our lands) without either consulting us or advising us of the contemplated treaty or giving us any opportunity of being present or having any agency in making said treaty. If such are the intentions of the Sauks (that they are we have no doubt) the effectuating of them will as your Excellency cannot fail to perceive operate most unjustly upon our rights and interests. Previous to the Black Hawk war of 1832 we the Foxes resided west of the Mississippi and owned the land in Iowa and the Sauks resided on the east side of the Mississippi. At the conclusion of that war at the treaty at Rock Island we consented that the Sauks should

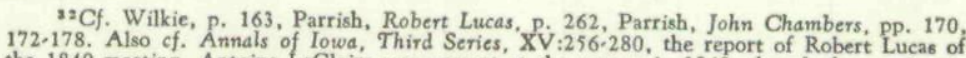
the 1840 meeting. Antoine LeClaire was present at the agency in 1840 , though there primarily for trading interests rather than as an interpreter, according to Lucas.- - Editor. 
come over and reside among us. It was agreed between us that the Sauks should reside in the lower end of the Territory and any of the Foxes who went and lived with them were to be considered Sauks and that any of the Sauks who remained with us should be considered as Foxes.

We the undersigned live at Powshiek's village on the Iowa river where all the Foxes reside. That those bands of Indians residing in the lower end of the Territory on the lower Des Moines do not alone constitute the Fox nation and that they have no right to sell any lands on the North east of the Des Moines without our consent. We make these statements for the purpose of showing that if we were disposed to investigate strictly the title to these lands we might be able to show a better exclusive title than the Sauks but we do not insist upon having this exclusive title all that we contend for is that we as the Fox nation shall be considered and recognized as such a constituent portion of the confederated Sauks and Fox nation as that no valid and binding treaty can be made or any portion of these lands can be purchased without our being parties to such $a$ treaty. We therefore hereby respectfully request your Excellency to hold no treaty for the purchase of these lands without giving us the usual dire notice of the time, place of holding the same, and giving us the opportunity of being present and participating in the negotiations.

We deny the right of the lower bands to cede away our land or make any treaty in relation thereto unless we are parties. And we for ourselves and the Foxes whom we represent protest against the validity of any treaty which may be concluded with out our agency.

Wan Co Shan She
Ai-Mir-i-wit
Kau-kau-ke
Mo-whou-ye
Mu chyne cume cut
Weshe kan koa skuck

Pia ton o qua

Mai nin no wan sit

Wan can tep

Cai mo to

Mes que qua on

Nan-pee-lau-skuck

The next year, 1842, when the sale was actually consummated, Chambers told the Indians to choose any of their white friends to help them make the treaty. They chose LeClaire and Davenport, and two others. ${ }^{33}$

LeClaire's responsibilities, as an Indian interpreter, trader, and latterly as an important landowner, had their vexa-

${ }^{33}$ See Annals of Iowa, loc, cit. The selection of LeClaire with the others suggests, accord. ing to the Lucas hypothesis that the "Company Indians" had triumphed over the Hardfish band and its company of Black Hawk followers. All of the four chosen by the Indians were traders identified with the American Fur Company and the Chouteau interests.-Editor. 
tious details, some not without humor, as the latter document found among his papers suggests:

Articles of Agreement between A. Leclair, of the County ot Rock Island, state of Illinois, of the first part and Lewis Savoy of the said County and State, of the second part, Witnesseth-That the said Leclair for, and in consideration of the services of the said Savoy, doth promise and agree to pay him $\$ 150$ per ann. For two years from the date of this investment: And he furthe1 promises to furnish him good wholesome diet, lodging and wash. ing and three wine glasses of liquor per day, -that is to say, one at morning, noon and night-and allow him 3 days at the end of every three months for such purposes as he may choose-provided, however, that the said Savoy shall not drink to intoxication, within the time first specified-than that part granting him three days holy day, be null and void of effect.

And the said Savoy of the second part, does promise and bind himself faithfully to perform all such labor as he may be put to be the said Leclair; and he further promises to abstain from drinking intoxicating liquors during every three months.

The parties to the foregoing contract, bind themselves, each to the other, the complete fulfillment, and strick observance of the foregoing agreement. Given under our hand and Seals this 18th

Teste-

M. S. Davenport

day of January, 1833.

\author{
Antoine Le Claire \\ his \\ mark \\ Louis x Savar
}

After Congress had ratified the "Black Hawk Treaty" of September 21, 1832, by its provisions the lands in the "Purchase" were thrown open to settlement, after June 1, 1833. Squatters or claimants began to filter into the region for settlement, many forehanded and without warrant of law. The whole purchase was as yet unsurveyed, and titles and boundaries to property were vague and productive of quarrels and litigation. One of these early squatters was a Dr. John Emerson, Army surgeon at Fort Armstrong, who had with him a slave named Dred Scott, and thereby hung an important tale. ${ }^{24}$ When the doctor was transferred to Fort Snelling three years later, 1836, he left to his good

\footnotetext{
34See author's article, "John Emerson, Owner of Dred Scott," Annals of Iowa, Third Series, XXI: $440 \cdot 461$.
} 
friend, Antoine LeClaire, the supervision of his properties in Iowa, a charge which the latter faithfully executed.

With confusion as to the bounds of claims existing, much heated argument arose, some not without important consequences to the history of the future town of Davenport. When two squatters, Spencer and McCloud by name, fell out over the priority of their claims to a certain half section of land bounded approximately by Harrison and Warren streets and the river and West Seventh street in the present City of Davenport, LeClaire bought them out for $\$ 150$. On the evening of February 23, 1836, at a meeting at Colonel Davenport's home on Rock Island, a partnership agreement was written and signed by eight men who took over this half section at a valuation of $\$ 2000$ with the purpose of starting a town site. The signatory partners were Antoine LeClaire, George Davenport, William Gordon, James May (by George Davenport, agent), T. F. Smith (by A. LeClaire), P. G. Hambaugh, L. J. Colton, Alexander W. McGregor."

At this time LeClaire was living on the log house that he had built in 1833, at Keokuk's insistence, on the site of the tent in which the Black Hawk Treaty was negotiated, the house in which he continued to live until the railroad locomotive's whistle echoed in the little town of Davenport.

In May, 1836, Major William Gordon ${ }^{37}$ surveyed the claim of the proprietors, and laid out streets and building lots, reserving three blocks for "public purposes," the present LaFayette Park, Washington Park, and the courthouse site in Davenport, first known as Bolivar Square. Now in 1836, with a new town planned in his busy brain, LeClaire began to devote his time increasingly to its promotion and

\footnotetext{
35Date of the partnership agreement as given in photostat of original document, Cf, Wilkie, 32.33, 161.163; Downer, and History of Scott County (1882) for other erroneously varying dates.

James May was a merchant and shipper of Pittsburgh, Penn., Colton and McGregor actual settlers along with Gordon, Hambaugh was in the U. S. military service at Rock Isalnd, later transferred.-Editor.

stWilliam Gordon, a native of Tennessee, an adventurer and eccentric, "settled" in a cabin on the left bank of the Mississippi prior to 1836, and disappears from record in 1843. See Wilkie, pp. 33,98 .
} 
growth. In that year, after Major Gordon had platted the claim, a sale of lots was begun, which, however, went quite slowly due to the uncertainty of title. At the end of the year there were only seven cabins built and less than a hundred residents on the left bank of the river, including several who had settled on their own claims within a short distance of the LeClaire's and who became very shortly leading citizens of Davenport. ${ }^{38}$

Together with Colonel Davenport, LeClaire built a hotel of logs on Front Street, near the foot of Western Avenue in 1836. One Edward Powers of Stephenson (later Rock Island) was the manager the first year. Here stopped in that year a young Vermonter who had halted in Ohio on his way west to engage in the business of transporting the United States mails. Now he brought his stagecoaches and horses to Black Hawk territory and acted as his own hostler at Powers' Hotel. He soon went on to live in Andrew, in Jackson County, and began the operation of several stage routes in that vicinity. No one guessed when he stopped at the Powers Hotel that he was destined to become the first governor of the new State of Iowa, in 1846. His name was Ansel Briggs."

When the Powers Hotel was opened November 15, 1836, with a dance as a house warming, LeClaire, although one of the builders, could not go, much as he liked to dance. He was down with inflammatory rheumatism. He had been treated by Dr. Bardwell of Stephenson, who was making no headway with his patient's illness. The night of the dance Dr. E. S. Barrows was called in consultation. Barrows was a Vermonter who in that year had settled in Rockingham, where he was the only physician between Dubuque and Burlington. Bardwell insisted his patient had dropsy; Barrows said it was rheumatism. On the night of November 15, Bardwell had brought along his dancing shoes and was in an evident hurry to go. LeClaire finally told him to go, and gave himself into Barrows' hands. The latter made twelve calls in as many days. The patient, agreeably to

s8Wilkie, p. 98; History of Scott County (1882), p. 720.

"Wilkie, p. 34. 
honorable custom, was thoroughly bled-and got well. About ten days later LeClaire drove to Barrows' home in Rockingham and voluntarily gave the doctor a handful of money, saying that he would pay "the balance some other day." The first payment consisted of $\$ 150$ in gold and silver. Later he gave Barrows a deed to a lot which the doctor afterwards sold for $\$ 1000 .{ }^{40}$

Dancing was a popular entertainment in those frontier towns. LeClaire not only attended dancing parties but gave them in his own home before Davenport came into being, when he and Marguerite still occupied their humble home on the island, or in the home site of Morgan's village, when the soldiers and settlers and their ladies, including Indian girls, came. With the growth of the town of Davenport, the little town quickly blossomed out with similar dancing parties early in its life; and LeClaire was always one of the party, as attested by the invitations found in his collection.

Among others is this invitation printed on white silk:

FARMER'S \& MECHANIC'S BALL

The company of $M$

is respectfully solicited

at a Ball to be given at the LeClaire Hotel,

in Davenport, on the evening of the 31st inst.

[1839]
A. LeClaire
Managers
N. Squires
N. M. Rambo
L. J. Center
C. Bardwell
W. Davidson
J. S. Sheller
J. L. Cook
T. E. White

Davenport was coming up socially, and lo! LeClaire's name led all the rest.

The LeClaire Hotel noted in the above invitation had been but recently built, a pretentious three-story building on the corner of Main and West Second streets, where the Putnam Building is now. In its day it was the most pre-

${ }^{4} \mathrm{H}$. E. Downer, History of Davenport and Scott County, quoting Willard Barrows" "History of Scott County," I:446 ff. 
tentious hostlery west of the Mississippi and continued so for many years. The tradition is that its cost was $\$ 35,000$. S. M. Langworthy of Dubuque in commenting that "The building material for the erection of the first hotel in Davenport called the LeClaire House, which I had contracted with LeClaire to furnish," indicates not only who the hotel was named for, but also its builder."

To this famous inn came many guests headed for business or pleasure. Southerners particularly came up the river with their families and stopped at the LeClaire House. The eastern end, or wing, was added later; it stands yet next adjacent to the east of the Putnam Building, with some of the old rooms and halls as they were built."

In 1838 "The First Proprietor" was busy extending the platting of the streets in The Reserve. Streets both here, and in the claim were named for his white friends of the Indian troubles, General E. Gaines, General Scott, General William H. Harrison, General Hugh Brady.

As he was laying out the streets, providing for the parks in the city, and preparing for the extension of the growing city into his reserve provided for in the treaty of 1832 , he did not forget the forces of religion in the community. An active Roman Catholic, even though not baptised until he was eighteen years old, for that church he made generous provisions. His active interest in the affairs of his church is indicated in his acquaintance with that peripatetic missionary of the early west, Father Samuel Mazzuchelli, whom he probably met on occasions in the latter's travels, and with whom LeClaire had close friendly relations. ${ }^{* 3}$ A letter from the priest in the LeClaire Papers suggests both the friendship and the difficulties facing pioneer missionaries:

4Downer, I:161; Iowa Journal of History and Politics, VIII:337.

${ }^{42}$ Ralph Waldo Emerson on his first visit to Davenport, Dec. 31, 1855, staid at the LeClaire House. In his comments in his journal he noted "no gentleman permitted to sit at the table without his coat." See also Davenport Gazette, Sept. 9, 1852.

${ }^{4}$ Wilkie's statement, (p. 37) "Religious services were held semi-occasionally at the house of Mr. LeClaire, in which a priest from Galena officiated," undoubtedly refers to Father Mazzuchelli. Father Mazzuchelli speaks in his Memoirs of "A certain M. Antoine Leclaire [sic], a devout Catholic, noted no less for his integrity, than for his wealth... the Mis. sionary [Mazzuchelli] with the assistance of Mr. Leclaire, principal proprietor of the new city of Davenport, in the month of April, 1837, laid the first stone of the church which was called Saint Anthony's." (pp. 190, 193)-Editor 
6 March 1837

Galena

Dear Sir,

I am compelled to write you from this place that on account of various circumstances I shall not be able to come to Iowa and Rock Island before the growing [sic] of the navigation. I had promised to travel lowa your way with Mr. Michael Connelly, but something happened which prevented my being in Galena on the appointed day so I disappointed him. On the first day of April you will see [me] at your place. My health is perfectly good which I hope to be the case with you and your family.

Your most ob.

Samuel Mazzuchelli

Sometime in 1838, LeClaire gave a whole block of land as the site of the first church building to be erected in Davenport, old St. Anthony's, on Main and West Fourth streets. There the beloved Father Jean A. Pelamorgues was the priest for so many years from 1839."

Church buildings cost less in those days as the following contract indicates, but the building must have been constructed in a-workmanlike manner and with good mortar, for it remains after a hundred years, a part of the present parochial school of St. Anthony's."

This indenture made on the 30th day of April 1838 between Mr. Antoine LeClaire, Wm. Watt, and S. Mazzuchelli on the first part and Mr. Adam Noel, Joseph Noel and John Noel on the second part witnesseth that Mr. Adam, Joseph and John Noel of the second part in consideration of the sum hereafter mentioned oblige themselves to stone foundation and the brick walls of the Catholic Church in Davenport of the following dimensions. The stone foundations will first consist of a wall one foot high and two feet wide made of small stone and then of $\alpha$ wall two feet and $a$ half high and two feet wide made with the best stone and mortar and foundations will be 25 feet and 8 inches wide by 40 feet and 8 inches long at the bottom and 25 feet by 40 at the top. The four outside brick walls will be 25 feet by 40 feet a brick and a half thick. The two inside walls will be supported by a stone foundation one foot

44 See footnote 43. Cf. Wilkie, pp. 71-73; quoting from The Catholic Advocate, Wilkie states the ground given was a "whole square, including ten lots." LeClaire was elected one of the first three trustees to serve the church for a term of three years, serving "the Catholic Congregation of Davenport and vicinity." -Editor.

${ }^{4}$ "LeClaire Mss, W. B. Watts married a niece of Antoine LeClaire, thus "the party of the first part" represents the LeClaire family. The cost of "Mason Work" was \$488, carpenter work, \$589. See Wilkie, p. 73. 
square and will be one brick thick and 10 feet high. On the gable ends the walls shall contain several flews, ending in one small chimney above the top of the roof. The windows, doors and flews shall be according to a given plan. All said work shall be done in a workman like manner with good mortar. In consideration of all said work Mr. Antoine LeClaire, Mr. W. Watt and Mr. S. Massuchelli promise to pay to Adam, Joseph and John Noel the sum of four hundred and twenty five dollars and all the necessary brick required for the building of said house, all other materials shall be furnished by the Contractor who also oblige themselves to have their contract completed by the first day of August 1838. In witness thereof the two parties have signed their names.

In presence of

witness James Lindsey

Antoine LeClaire
W. B. Watts
Samuel Mazzuchelli
Adam Noel
Joseph Noel
John Noel

There is a similar contract with Nathaniel Squires, carpenter.

Later he gave the land and helped to build St. Marguerites Church at Iowa and East Tenth streets, now succeeded by Sacred Heart Cathedral. His generosity was not limited to his own church people however. He helped the newly organized Protestant groups as well."

When his neighbors and townspeople thought of Antoine LeClaire the word generous followed the thought. "Illustrations of his generosity are numberless. In the first train to cross the first bridge over the Mississippi, April 21, 1856, came a considerable French contingent. LeClaire took them under his wing and established them in one of his 'additions.' Almost till his death ... he was known as 'the moneyed man of the town,' celebrated as 'the original proprietor of Davenport.' In 1858, when the Pioneer Settler's Association was organized, LeClaire presiding, a cane of

${ }^{4}$ LeClaire sold to the First Baptist Church of LeClaire 2 lots, lot 10, blk, 8, lot 4 , blk. 25 , for $\$ 25$ and \$1: The First Baptist Church of Davenport, property at Brady and 4th St. with quit claim, for $\$ 2$; the Congregational Church, Davenport, lot 3 block 48 , for $\$ 100$ (see also Annals of Iowa, First Series, I:148); Christian Disciples, LeClaire, Iowa, lot 4, blk. 15. for \$15.-Editor. 
native hickory with a gold band bearing his name was presented to him, to be handed down to succeeding presidents. The eighth toast on this occasion was 'to Antoine Leclaire [sic], first in settlement, first in efforts to make our city peerless among rivals, first in the esteem of his fellow citizens, first President of this Society; may his shadow never be less.' (From being very slight he had grown exceedingly stout)."47

When outsiders thought of the new town of Davenport in a business or in any other way, they thought of LeClaire, for the First Proprietor was intimately associated in many ways with the life of his city. Even before the days of John Wilson's ferry LeClaire helped to establish a ferry across the Mississippi, in 1834. In 1838, he took up the duties of postmaster in the new-born town, and served until Duncan C. Eldridge succeeded him two years later. He had helped to build two hotels in Davenport, had opened a large mercantile and trading store with George Davenport in 1838. In 1850 his versatility of interest was demonstrated in the establishment with others of a foundry on Front Street, east of Scott. He also encouraged business in Davenport by becoming a silent partner in mercantile endeavors or in furnishing sites for such ventures. ${ }^{* 8}$

He was also civic minded, as his largesses to the church groups and his provisions for public parks evidence. In 1840 the two year fight over the selection of a county seat between Rockingham and Davenport was finally settled in favor of the latter, with large help from the proprietors. LeClaire and Colonel Davenport, had promised a site for the courthouse, in Bolivar Square, an offer instrumental in settling the prolonged and bitter dispute. The new county had no money or credit for its construction, however. "When the

\footnotetext{
17Houghton, Our Debt to the Red Man, p. 91.

${ }^{48}$ U. S. Post Office Department to C. E. Snyder, Sept. 26, 1941; Annals of Iowa, First Series, I:147; Richter, op. cit.

The Davenport \& ${ }^{2}$ LeClaire firm of Antoine LeClaire, George L. Davenport, Harvey J. Hughes, John A. Boyd began operations in spring of 1851. It was dissolved in September, 1851 , though the name retained, when the remaining partners bought out $\mathrm{H}$. Hughes. LeClaire was one of 12 incorporators of the LeClaire \& Davenport Railroad Company in 1853 . He also owned a stone quarry at LeClaire, and in the earlier years was financially interested in Rock River navigation.-Editor.
} 
contractor felt a doubt as to the responsibility of the list [of men pledged to contribute to the building fund] LeClaire told him to go ahead. That appears to have been sufficient, but the time came when there was no money for the contractor, who promptly sued Mr. LeClaire. The latter had no money; he went to St. Louis and appealed to his friend, Chouteau, the wealthy French fur trader, offering as security a mortgage on his Davenport lands. Chouteau bade him. go to the strong box and help himself, refusing any mortgage. Thus the court house was built."

As LeClaire's real estate and other financial commitments increased and drew the focus of his attention toward their care, and as the Indian tribes moved farther and farther west in an unending if halting retreat across the Missouri, he gradually broke his connections with that older phase of his earlier life, as an interpreter, a trader and a dealer in Indian annuity goods. The last treaty to which his name is known to have been affixed was in 1842. In 1839, at the time he was opening the Reserve for town settlers, as he was bestowing largesses upon church groups, he severed his relationship with the Chouteau interests in St. Louis as their agent, or representative, or competitor, as the following agreement shows: ${ }^{50}$

Form of an Agreement made and entered into at Davenport Iowa Territory this 31st day of August 1839 by and between Antoine LeClaire of said place and P. Chaouteau Jr. co. of St .Louis, Missouri, witnessed that the said Antoine Le Claire for and in consideration of the sum of Five Thousand dollars to be paid to him by P. Chaouteau Jr. \& Co. (soon after the payment of the annuities due the Sac and Fox Indians for the year 1839) agrees to sell and relinquish to said Chouteau \& Co. a certain claim which he has against the Sac and Fox Indians amounting to about Eight Thousand and fifty dollars and which claim it is understood included the whole amount of the indebtedness of said

\footnotetext{
49Wilkie, 54-56, History of Scott County, 1882, pp. 262-70; Houghton, op cit., 89.

$5^{\circ} \mathrm{LeClaire}$ Mss. See also the Report of Robert Lucas, Superintendent of Indian Affairs in the Territory of Iowa, Annals of Iowa, Third Series, XV:256-80. From these accounts LeClaire continued closely associated with the Chouteau interests. In 1838 Joseph Street, agent at the Sauk and Fox agency at Rock Island, removed to Agency City. This probably marked the beginning of the end of LeClaire's days as a government employee. His real estate interests were now crowding his time. Between 1838 and 1853 LeClaire was a party to the granting of 459 deeds or recognizances in Scott Co. And between 1838 and 1846 he acquired 91 additional titles or properties in Scott County alone. The 7 th LeClaire addition to Davenport was begun in June 1854, the 9th in September, 1855. See Recorder's Office, Index to Deeds, Scott County.-Editor.
} 
Indians to Le Claire up to this date and the said Le Claire is to put said P. Chouteau \& Co. in possession of all the notes, accounts, and papers relating to said claim and which may be necessary to secure said amount from the Sac and Fox Indians at the payment of their annuities for 1839 and it is further understood between the parties to the agreement that the said LeClaire is to give said P. Chouteau \& Co. all and every aid which may be considered necessary to secure the ultimate payment of said claim by the Indians and it is expressly agreed upon by said Le Caire and Chouteau \& Co. that the said Le Claire is not hereafter to carry on any trade, traffic or barter with the said Sac and Fox Indians either for himself or others directly or indirectly except he should have the written or verbal order of said P. Chouteau, Jr. \& Co. or their agents this last condition is to continue in force so long as said P. Chouteau \& Co. carry on trade with the Sac and Fox Indians for the faithful performance of which the sciid Le Claire binds himself in the sum of Five Thousand dollars to said P. Chouteau \& Co.

In testimony whereof the parties have hereunto set their hands and seal this 31st day of August, 1839.

Witnessed to Antoine Le Claire's Signature Antoine Le Claire Seal Jas. M. Bowling

Witnessed to P. Chouteau \& Co. $\quad$ P. Chouteau \& Co. Seal Adam D. Stuart

His many interests developed rapidly in those years of the forties and fifties, far beyond the simple beginnings of his little city. One of those interests was his farm, which stretched north and east from his house. Stephen H. Hayes in "Letters from the West" in 1845 writes: "Antoine LeClaire, a half-breed Indian, is now proprietor of this region. He has a fine farm on which he has good buildings, a flour mill, a young orchard, etc. He is I think, the largest man I ever saw, very dark for an Indian, though he facetiously remarked that he 'was the first white man who ever settled there west of the Mississippi. '

That orchard had to be sacrificed for a dearer object. In the 1850's Davenport listened to the sound of railroad talk that was rolling up in great volume out of the East. The Chicago and Rock Island reached the City of Rock Island in 1854; but Davenporters were not ready to leave the mat-

51owa Journal of History and Politics, XX:41 ff. 
ter there. They got plans into shape for their own railroad to the west, before the locomotive whistle was heard from the east side of the river. Articles of Association for the Mississippi and Missouri Railroad were adopted February 22,1853 . On January 17 of that year the Illinois legislature chartered the "Railroad Bridge Company." The engineers' plans for the bridge fixed its Iowa terminal so that the railroad would run off into LeClaire's orchard. He was promoting the railroad and the bridge, but he still tried to save his orchard. The engineers were firm, however, and LeClaire gave in. ${ }^{52}$ The first earth was turned for the Mississippi and Missouri Railroad, the first railroad to begin construction west of the Mississippi, near LeClaire's residence, that simple little house that he built where Keokuk had said he should back in 1832. The ceremony occurred on the first of September, 1853. LeClaire turned that first shovelful of dirt and made a little speech: "This day is propitious to the generations of this State and I feel highly honored in having been elected as the one to accomplish this beginning. Years ago, the great Chief Keokuk gave me freely of the lands hereabout, and I, in turn, am giving freely to this railroad of these lands, for right of way, for its tracks and for its shops and yards. This building here (indicating the home built years before for his wife), shall be, if desired, the first depot of any railroad in Iowa." ${ }^{1 / 8 s}$

That little house was used as a depot for a good many years; and now it stands on the railroad right of way near East Fifth Street and Pershing Avenue, decorated with a bronze medal in honor of its history and its builder.

On July 10, 1855, there came to Rock Island a locomotive of 25 tons net weight, bearing in gold letters the name "Antoine LeClaire." The sand box on the border of the engine was of bronze with a bust of LeClaire on one side and of Pocahontas on the other. ${ }^{.4}$ He was getting to be a

$\$ 2$ Antoine LeClaire sold a strip of land along the river to the Mississippi and Missouri Rrd. for the handsome sum of $\$ 15,000$, on the condition that the first division of the road between Davenport and Iowa City pass through that point, otherwise title to revert to LeClare. Record Book of Deeds, K, p. 189 .- Editor.

${ }^{5}{ }^{5} \mathrm{See}$ footnote 52, also Rock Island Magazine, 70th Anniversary Number, 1922.

stlbid. 
pretty big man, this Indian born in a trader's station up in Michigan, in 1797.

Passing the old home over to the railroad meant a new home for the First Proprietor. He chose a commanding site on the hill just north of East Seventh Street between Farnam and Grand. There he built a large brick house for Marguerite and himself; it is of the kind called a mansion in those days, done into apartments now. While it was building they lived temporarily in a little house at West Third and Main streets, where the Lane Building is now.

The prominence of this first citizen was demonstrated in yet another manner, proving his position was more than that of his own city, but was known and recognized throughout the state. The Iowa State Bank was authorized by the state General Assembly by an act of March 20, 1858, following the adoption of the Constitution of 1857, which permitted such legislation. The Bank was set going under the direction of a commission of nine men with branches in several of the larger cities of the state. It issued currency in various denominations. The five dollar bills it put into circulation bore the likeness of Antoine LeClaire.

But neither the Iowa State Bank, which continued until the National Banking Act of 1863, authorizing National Banks with currency issuing powers, made the State Bank unnecessary, nor his picture on its currency, could save LeClaire from involvement in the financial crisis which soon enveloped the middle west. LeClaire had become a very wealthy man for that period in the west. He would easily have been rated at half a million dollars. His land holdings were extensive. His investments were numerous; but they were investments in creative undertaking and in no speculative ventures. He had much money loaned to business men who needed help. His name was on a large amount of commercial paper, for he was always helping folks. Then came the smash of 1859. The Cook and Sargent Bank failed. Burroughs and Prettyman, pork packers and millers, likewise failed. LeClaire was involved with both concerns, and with many others equally hard pressed. 
And there was no money in circulation. LeClaire was the only man in the region who had credit abrocid. He became deeply involved, pledging thousands of acres of his land for loans to help straighten out the tangled finances of his town. ${ }^{\text {si }}$

Those were trying times, and the time came when it had become hard to be a big man. LeClaire was, in 1861, sixty-four years old, and he was still carrying a heavy load. Something broke, and even his big frame would not carry it longer. In the midst of the excitement of the first months of the Civil War, then but five months old, the word went rapidly down the hill on the evening of September 25, 1861, that The First Proprietor had died. They said he had had another stroke; and they who knew him best knew that back of those strokes lay the strain and weariness of being the big man when the hard time came."

The Davenport Daily Democrat and News said, September 29, 1861, corimenting on the funeral of Antoine LeClaire;

"Davenport has never seen a ceremony more imposing than that with which her first settler was buried. Business was almost suspended, and the street crowded with spectators, as the body of him who had been seen on those streets almost every day for thirty years was carried in solemn procession to its long home.

A little after nine o'clock the funeral ceremonies were commenced at the house of the deceased by the recital of the usual prayers of the Catholic Ritual. The Clergymen present were the Rev. Fathers Pelamorgues, Trevix, Cosgrove, and Nierman of Davenport, and Murphy of Rock Island. Bishop Smyth, of Dubuque, would have been present if his engagements had permitted. On leaving the house, the procession was led by the cross-bearer, followed by 16 acolytes in their appropriate dresses, the clergymen above named, in their robes, and The Society of Old Settlers, of which Mr. LeClaire was the first President. Then came the

\footnotetext{
${ }^{55}$ The First National Bank of Davenport was the first of the newly created national banks to open its doors in the United States, June 29, 1863. See J. M. D. Burroughs, Fifty $\Upsilon_{\text {ears in }}$
Iowa, pp. $122 \mathrm{ff}$.

5 "LeClaire suffered a stroke one week prior to his death.
} 
six pall-bearers, who carried between them the pall, after whom followed the corpse, in a superb coffin, borne on a bier of ten men, who were relieved at intervale by ten others. On each side of them walked eight young ladies, beautifully dressed in white. After the coffin, followed the family of Mr. LeClaire, in three carriages; then the members of the Sodality, and the choir of Ste. Marguerite's, of which Mr. Leclaire was a member, having been always a great lover of music, and the first singer of the first church founded in Davenport. Then came a long line of the children of the Catholic schools, carrying their beautiful banners, and then a great number of citizens on foot and in carriages. The procession moved slowly down Farnum Street to Second, along Second to Main, and up Main to St. Anthony's church, a handsome and substantial structure, in the erection of which $\mathrm{Mr}$. LeClaire gave a large material aid. Here a short service was performed by the Rev. Father Pelamorgues. The funeral cortege then proceeded to Ste: Marguerite's Church which was built, we believe, entirely by Mr. LeClaire. This church is a very beautiful building, and with its handsome spire forms one of the most prominent and striking objects in the city when seen from a distance. So large was the procession, that it filled the Church, which was appropriately illuminated and draped in black. Here the Rev. Father Pelamorgues, delivered a very feeling address on the life and character of the deceased. The choir then sung the Gregorian Mass for the Dead, and Pope's beautiful ode, "The Dying Christian's Address to his Soul." After which the solemn ceremony of High Mass for the Dead, was celebrated by the Rev. Father Trevis, and the absolution pronounced by the Rev. Father Pelamorgues. The corpse was then conveyed into the Church yard, and buried near the S.E. corner of the Church, in a spot long set apart by the Clergy as the place where the mortal remains of the benefactor of Ste. Marguerite's should rest."

Marguerite, granddaughter of Ac-co-qua, continued to live in the big house on the hill until October 16, 1876. She was buried by the side of her husband, but in later years 
when The Cathedral of The Sacred Heart succeeded St. Marguerite's Church on that site, the bodies and the tall shaft erected over their graves were moved to St. Marguerite's cemetery.

Antoine LeClaire had made his will March 7, 1861. He left his estate for the use of Marguerite during her life, after which it was to be divided into equal shares for his brothers Francois and David and for each of their children, for his nephew L. A. LeClaire and for several nephews and nieces of Mrs. LeClaire, making thirty shares in all. He requested his friends G. C. R. Mitchell, Charles E. Putnam, and George L. Davenport to make the division into shares after the death of Marguerite. She and George L. Davenport were to act as executors. ${ }^{\text {"r }}$

The estate was badly involved and the settlement of it ran out over many years. The appraisers valued the real estate at one hundred sixty-one thousand nine hundred and ninety-one dollars, a valuation which increased largely before Marguerite's death. The original appraised value of the personal property was $\$ 31,755.43$, of which very little was actual money. ${ }^{\mathrm{s}}$

Among the liabilities were a series of notes held by three Massachusetts banks, in Hingham, Boston, and Greenfield, amounting to $\$ 95,491.68$, secured by real estate, the debts he had incurred to save his city and his friends from financial devastation. Other liabilities included $\$ 30,000$ of Burroughs and Prettyman paper, on which he was the endorser, all of which was past due and protested. This too was secured by real estate. In addition there were $\$ 7000$ in taxes for 1860 and 1861. In a partial report made to the court, March 31, 1877, Davenport said, "I found the estate weighed down with a load of indebtedness and notwithstanding the necessity and the protracted and expensive litigation through which it has passed I shall be able in surrendering my trust to turn over to those interested on estate largely increased in value."

\footnotetext{
${ }^{57}$ George L. Davenport was the son of LeClaire's good friend, Col. Davenport.

$\$$ About $\$ 2300$.
} 
Included in that litigation was a lawsuit brought by Captain James May, growing out of the partnership arrangement for the section of land above the upper rapids where little city of LeClaire grew up. May, an earlier warm friend of Antoine, and associated also with him in the town site company for the City of Davenport, had bought out Enoch March in that earlier arrangement. Now he sued the estate for $\$ 35,000$ upon some claim growing out of that partnership. The case dragged out a tortuous history in the courts. In a report by George L. Davenport in the June term of court in Scott County, 1877, he scid:

"This action was commenced by James May against Antoine LeClaire April 4th, 1861, and upon his death was revived against the representative of his estate. It was instituted to enforce certain contracts for the settlement of unadjusted claims between them and involved a demand for the transfer to May under said contract of a certain mortgage for $\$ 35,000$, made by one A. H. Davenport on lots and lands in LeClaire, Iowa. At the May term, 1865, of the United States Circuit Court for Iowa, the case was dismissed whereupon the complainant appealed to the United States Supreme Court, which at the December term, 1869, reversed the decision. Case was again heard in the U. S. Circuit Court in the October term of 1871, and J. B. Edmonds was appointed master to take an account. He awarded May about $\$ 9000$, which was paid in full. May was not satisfied however and he reopened the case in an amended bill."

Davenport goes on to say, "In a communication addressed to the attorneys for the estate from Hon. C. C. Cole, solicitor for complainant, of date April 12, 1877, he expressed his own convictions concerning his client as follows towit: 'It is perhaps due to you to say in words what perhaps you have inferred before that I do not believe May to be sane on the subject of his litigation with LeClaire and Davenport; I find him entirely unmanageable.'

"This frank confession states an undoubted truth and explains this protracted litigation. No other importance however should be attached to it than that it is attended with 
considerable expense, and prevents a settlement of the estate."

By the time of Marguerite's death the executors had so conducted the estate and paid creditors that they had handled over $\$ 304,000$ in cash, of which about $\$ 15,000$ had gone to her. In Davenport's report of June, 1877, cited above, he showed lands still held by the estate in Calhoun, Cerro Gordo, Carroll, Franklin, Iowa, Jones, Poweshiek, and Louisa counties as well as in Scott County. At the November term of the court in 1877 it was shown that money was in hand to make a distribution of the thirty shares in the amount of $\$ 2,500$ each, and there were evidences of a further similar distribution. In 1881 some of the heirs petitioned for the removal of Davenport as executor on the grounds of extravagance and mismanagement, but the court refused the petition. Later on Davenport resigned, and Louis A. LeClaire, Sr., Antoine's nephew, who had acted as his secretary in his later years, succeeded him. It was not until November, 1893, that Louis A. LeClaire submitted to the court a last report showing a few odds and ends of credits and debits settled up and prayed the court to declare the estate closed.

The First Proprietor had died broken by anxieties and burdens which came because his great spirit hastened to the sustenance of his city and his friends when the economic tornado came. He had laid the corner stone of a city, had been its builder; his soul stood by it in storm, and his sturdy body broke under its weight. He was a big man, this LeClaire!

-The Reverend Charles E. Snyder, of Davenport, Iowa, is minister of the First Unitarian Church of that city. Author of several studies in American history, Dr. Snyder contributed "John Emerson, Owner of Dred Scott," to the October 1938 number of THE ANNALS OF IOWA. 
Copyright of Annals of Iowa is the property of State of Iowa, by \& through the State Historical Society of Iowa and its content may not be copied or emailed to multiple sites or posted to a listserv without the copyright holder's express written permission. However, users may print, download, or email articles for individual use. 